\title{
静電相互作用を利用したトポロジー高分子の合成
}

末端反応性高分子前駆体（テレケリクス）の静電相互作用による自 己組織化・超分子形成と共有結合固定を統合し, 多様な非直線（多分 岐・多環）状高分子トポロジーを自在に設計・合成する新しい高分子 合成プロセスを開発した。これにより，「かたち（トポロジー幾何 学)」から始める「高分子トポロジー化学」が誕生した。

\section{手塚 育志}

\section{1.はじめに}

高分子の 1 次元構造設計の自由度が，連鎖的な 1 次元的 成長（低分子モ/マーの重合）で得られる直鎖状だけでな くさまざまな非直鎖 (分岐・環) 状へと拡張され, ス夕ーポ リマー，ポリマクロモノマー，デンドリマーなどの多分岐 高分子による機能材料開発が急速に進展している。こうし た非直鎖状高分子は，そのユニークな「かたち」に由来す る新規特性の発現亡とあに, 分子デバイス・分子マシンを 目指すナノテクノロジーの基盤技術として注目されてい る。本稿では, 自己組織化 (self-assembly) をキーワードと する新反応プロセスによる多様な非直鎖状（とくに環状お よび多環状) 高分子の自在な設計 (高分子卜ポロジー化学) について紹介する ${ }^{1 j ~ 6) 。 ~}$

\section{2. 単環状・多環状高分子トポロジー}

「末端」之「分岐」は，多様な 1 次元的な「かたち」を分 類・識別する基本的な幾何学パラメーターであり, 実際こ のアルゴリズムは指紋認証にも応用されている。高分子の 「かたち(トポロジー)」も基本的には「末端」と「分岐」 によって識別される（図 1) ${ }^{7)}$ 。

さらに，高分子セグメントはトポロジー的な屈曲性をむ ち, 全長を変えずに 1 次元的な「かたち」を变形させるこ とができる。したがって, 円形, 三角形, 四角形は相互に

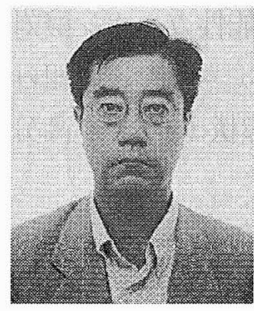

TEZUKA, Yasuyuki 東京工業大学大学院理工学研究 科有機・高分子物質専攻（152-8552 目黒区大岡山 212-1, S8-41)・教授, Dr. Sci., 工学博士.1982年 東京 大学大学院工学系研究科合成化学専攻博士課程中退. 1979-1982年 ベルギー・ゲント大学有機化学研究所留 学. 専門は高分子合成化学, 高分子卜ポロジー化学.

Topological Polymer Chemistry by Electrostatic Self-Assembly
直鎖および分岐状高分子
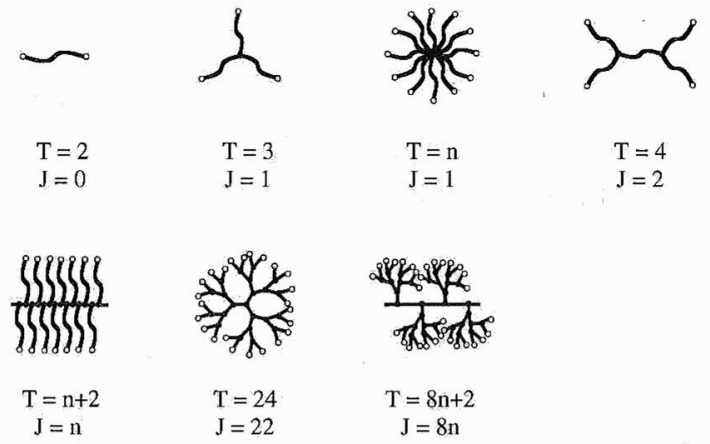

単環および多環状高分子
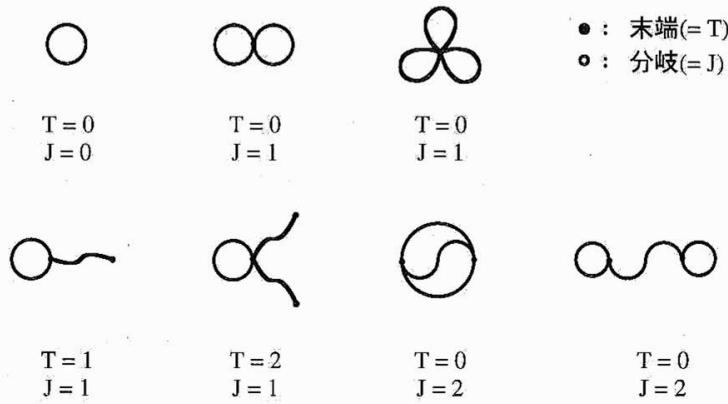

図 1 直鎖, 分岐, 扔よび環状高分子構造と末端, 分岐構造 パラメーター

変換できる等価なトポロジーとなる一方，末端をもつ直線 または曲線とはトポロジー的に非等価となる。こうした高 分子の「かたち」を特徴づけるトポロジ一的（柔らかい） 性質は，一般の低分子化合物やデンドリマーに見られる， 原子間の結合角および結合距離の不変性に基づくユーク リ％ト的（硬い）性質とは対照的なむのと考えられる。ま たトホロンー幾何学的に最も単純な 1 次元図形は, 直鎖 （末端数 $=2$, 分岐数 $=0$ ）ではなく, 環（末端数 $=0$, 分岐 


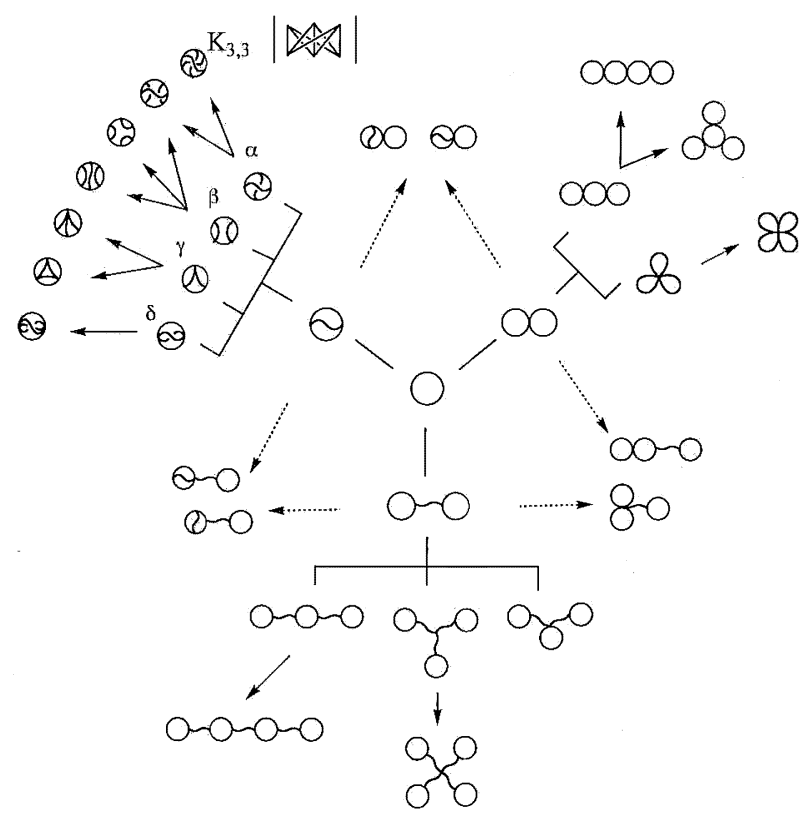

図 2 単環および多環状高分子トポロジーの系統図 (Ring Family Tree)

数=0）であることあ興味深い ${ }^{81,9 \% 。 ~}$

非直鎖状高分子トポロジーのうち，末端（自由分岐鎖） のない単環および多環構造を階層的に分類すると，図 2 に 示す系統図 (Ring Family Tree) が得られる10〉。単一の単 環トポロジーから出発して 3 種の双環トポロジー，すなわ ち縮合型 $(\theta$ 型)，スピロ型（8の字型），および連結型（手 錠型）が生じ，さらに 15 種の 3 環トポロジーへと発展す る。このうち, 4 種の縮合型構造は, それぞれ $\alpha, \beta, \gamma$, およ び $\delta$ 型と称される。また， 2 種のスピロ型および 3 種連結 型トポロジーがあり, 残りの 6 種は双環卜ポロジーと単環 トポロジーのハイブリッド構造である。また，4 環トポロ ジーには, トポロジー幾何学で特異な非平面グラフとして 知られる $\mathrm{K}_{3,3}$ を含む多くの構造が含まれる。

一方, 高分子合成化学の対象としてこれら多様な多環高 分子トポロジーは，これまでほとんど取り上げられてこな かった。しかし近年, 高分子の分子内環化反応で通常必要 となる希釈条件による非実用性を克服する新たな単環卜ポ ロジーの効率的合成プロセスの開発が進められている。ま た 8 の字型高分子の合成についても，いくつかの先駆的な 研究が行われてきた。これら単環状および多環状構造を含 む高分子群は, 末端吕存在しないというトポロジーに由来 する非レプテーション型（またはアメーバ型）ダイナミク スをはじめとするユニークな物性が予測され111 13)，その 実用的反応プロセスの開発は，これまでの直鎖状および分 岐状高分子を基礎としてきた高分子材料開発パラダイムの 転換にもつながる革新的技術となると期待される。

\section{3. テレケリクスの自己組織化と共有結合変換}

生体高分子 (たとえば酵素タンパク質) では, セグメン
卜内部の適切な筒所で作用するさまざまな非共有結合性相 互作用（方向性のある水素結合や配位結合，および方向性 のない静電相互作用や疎水結合など）を組み合わせて, 自 発的な高次構造形成（自己組織化）が生じ, 生体系の化学 反応プロセスでの選択的・効率的触媒となることが知られ る。このように非共有結合性相互作用によって高次構造を 形成した自己組織化集合体は, 超分子 (supramolecule) と 呼ばれ, 刺激, 環境, 基質に対する感応性 (adaptability), 動的な構造変化 (dynamic restructuring) などの構造の柔 軟性に基づくユニークな特性を示す。しかし一方, 超分子 の柔軟性は安定性・耐久性の欠如にもつながり, 材料設計 の立場からは弱点となる。実際, 酵素夕ンパク質分子の折 りたたみでは, タンパク質分子中の特定アミノ酸に含まれ るチオール基の酸化によってジスルフィド結合（共有結 合）が生成し，構造の安定化が図られている。

筆者らは, 自己組織化・超分子形成のコンセプトを合成 高分子の 1 次構造の設計に適用し, 合成高分子の末端に導 入したイオン性官能基（イオン対）による静電相互作用を 自己組織化の駆動力として利用することによって,「仮止 め」された超分子構造を形成し，さらにこれを共有結合・ 固定化する新たな高分子合成プロセス (electrostatic selfassembly and covalent fixation) を開発した ${ }^{1) ~ 6) 。 こ の シ ~}$ ステムでは，高分子末端に導入したひずみをあつ環状アン モニウムカチオンと適当な求核反応性をむつカルボン酸ア ニオンとのイオン対に基づく静電相互作用と，その加熱に よる開環共有結合化反応とを組み合わせている。

これまでこのプロセスは，スターポリマーやモデルネッ トワーク，执よびポリマクロモノマーなどの分岐掞よび網 目モデル高分子, さらにグラフト共重合体やネットワーク 共重合体などの多成分分岐, 網目共重合体の効率的合成に 用いられてきたが ${ }^{14)}$ ，さらに最近，多様な環状・多環状高分 子群の効率的合成に適用された ${ }^{15)}$ 。実際，5 員環アンモ二 ウム塩を末端基とする直鎖㧍よび分岥テレケリクスを調製 し，対アニオンとして多価カルボン酸アニオンを導入した 後, 適当な希釈条件下で加熱処理すると，5員環状アンモ ニウム塩の定量的な開環反応が進行し高分子末端のイオン 結合が共有結合に変換される。このとき，バルクまたは高 濃度溶液中では分子間反応が優先して鎖延長または架橋生 成物が得られるのに対し, 希釈条件では分子間反応が抑制 されカチオンおよびアニオンの電荷バランスを保った最小 単位での高分子集合体 (超分子) 構造が共有結合化され, 単環掞よび多環高分子が生成する。たとえば，両末端反応 性（2官能性）直鎖テレケリクスと 2 官能性カルボン酸対 アニオン, または 4 官能性カルボン酸対アニオンとの組み 合わせから，それぞれ単環状，および双環状 (8の字) 高分 子が高收率で得られた（図 3 $)^{16) ~ 18) 。 ~}$

さらに，環状アンモニウム塩基はテレケリクスの末端に 限らず, 高分子セグメントの内部に導入することもで 
$1+1$ 集合体<smiles>c1ccccc1</smiles>

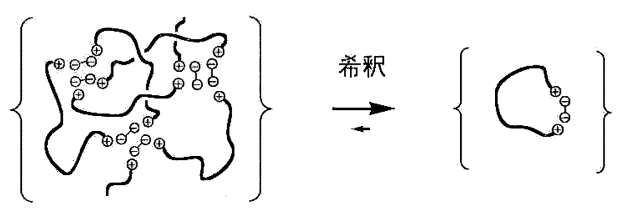

$2+1$ 集合体
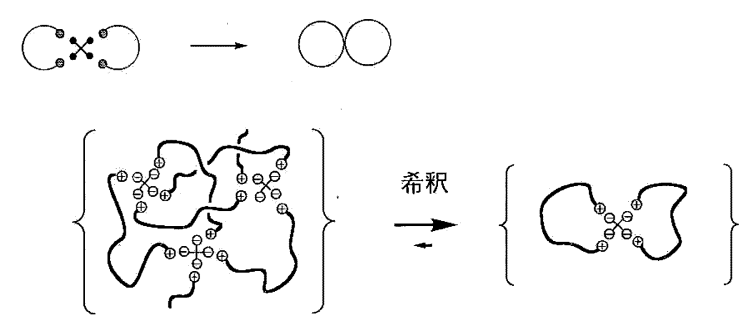

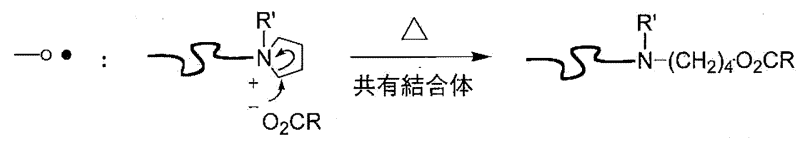

図 3 高分子イオン対の静電相互作用による自己組織化と共 有結合固定
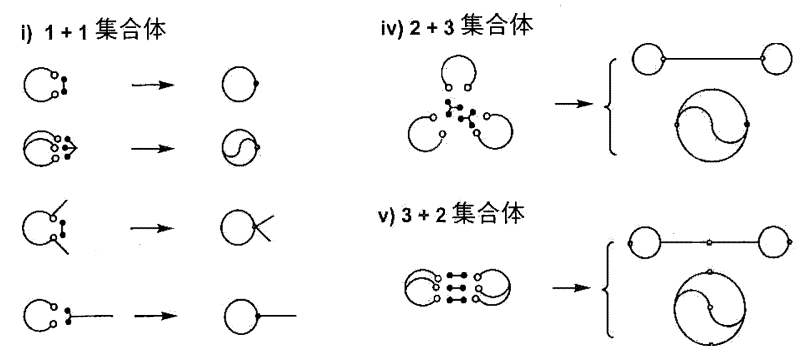

v) $3+2$ 集合体

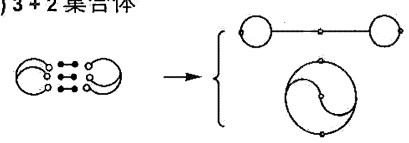

ii) $2+1$ 集合体

Cxo $\rightarrow \infty$

vi) $1+1+1$ 集合体

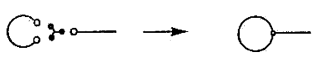

iii) $3+1$ 集合体

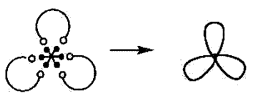

C:- $\rightarrow \mathrm{O}$

図 4 テレケリクスの自己組織化上共有結合変換に基づく高 分子卜ポロジー設計

き19)，また高分子カルボン酸対アニオンを用いて静電相互 作用による高分子-高分子間の自己組織化集合体を形成す

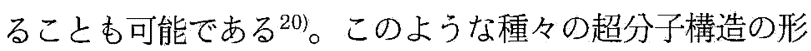
成と共有結合変換によって, 多環状卜ポロジー構造だけで なく，環一鎖構造を組み合わせたトポロジーブロック共重 合体（おたまじゃくし型トポロジー）の合成も実現した (図 4) ${ }^{15)}$ 。また, 超分子形成に用いる多価カルボン酸にア リル基などの官能基を導入することによって，環状マクロ モノマー，環状テレケリクスなどの反応性環状高分子前駆
体が得られ，さらに高度な高分子トポロジー設計に利用さ れた $21 \sim 23)$ 。

\section{4. 高分子トポロジー異性}

異性（isomerism, ギリシャ語のisos (equal) と meros (part) からの造語) は化学の基本概念のひとつであり, 化 学組成が同一（したがって分子量も同一）で性質の異なる 一組の化合物が異性体 (isomer) 亡なる24),25)。異性体の性 質は種々の「構造（かたち）」の違いに由来し, 化合物の静 的・動的構造を反映した多くの異性形式がある。有機化合 物の異性体は, 構造異性体 (constitutional isomer) 亡立体 異性体 (stereoisomer) に大別され, 前者では, 化合物を構 成する原子または原子団の結合様式 (connectivity) が異 なり, 一方後者では, 結合様式は同一であるあのの, 結合 角, 結合回転などに由来するコークリりト幾间学的構造パ ラメーターに違いがある。

また, 構造異性体と立体異性体には, 分子骨格を折れ線 グラフで表した「分子グラフ」による異性体間の相互変換 （異性化）の表現にあ明確な違いがある。すなわち前者で は, 結合様式 (connectivity) の違いに対応して, 分子グラ フの少なくとも（適当な） 2 力所の切断と再結合が求めら れる。一方後者では, 分子グラフの切断は必要なく, 結合 角, 結合回転に対応する分子グラフのユークリッド幾何学 的パラメーターを可変化（トポロジー化）することによっ て相互変換される。

ここで，屈曲性セグメントで構成される非線形高分子の 異性形式には，ユークリッド幾何学的構造パラメーターに 依拠する一般の有機低分子化合物には見られないトポロ ジー的特徴が認められる9。その代表例は, 単環 (ring), 結 び目 (knot) およびからみ目高分子 (catenane) であり, こ れらはとあに，2 本の直鎖高分子前駆体を礼じり合わせた
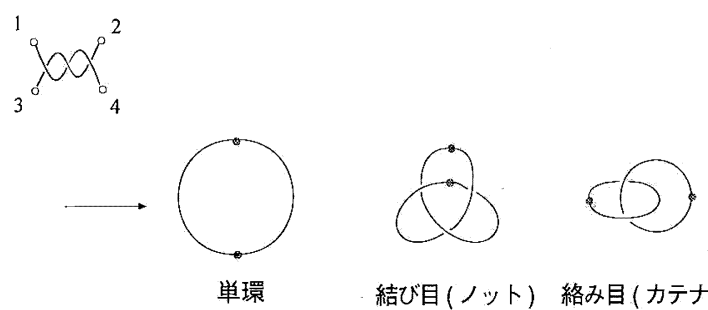

$(1+3 \& 2+4)$

結び目 (ノット) 絡み目 (カテナン)

$(1+2 \& 3+4) \quad(1+4 \& 2+3)$
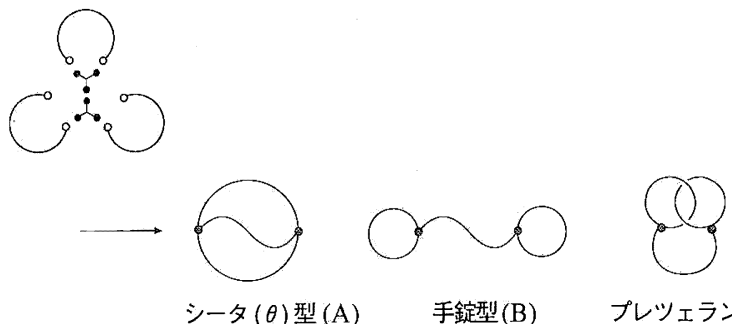

手錠型(B)

プレツェラン型 $(\mathrm{C})$

図 5 単環状および双環状高分子卜ポロジー異性体 
うえで，末端を連結することにより合成できる（図 5 ${ }^{26)}$ 。 したがって，これらは拉いに異性体となる。な抢このプ ロセスでは，独立した 2 つの単環高分子を生成することも できるが，これらと先の 3 者とは，シクロへキサンとシク ロプロパン 2 分子との関係之同様，それぞれ別の生成物 (product)であり，異性体とはならないことに注意したい。

筆者らは，高分子卜ポロジー異性体となる 3 種の双環状 高分子（すなわち，図 5 に示す， $\theta$ 型高分子 $\mathrm{A}$, 手錠型高分 子 $\mathrm{B}$ ，招よび手錠型の環成分がからみ目となったプレッェ ラン型高分子 C）の合成，分離，さらに相互变換について 検討を進めている(図 4) ${ }^{15,27) ~ 29) 。 こ こ て ゙ ， A ~ と ~ B （ ま た ~}$ は A と C) は，「単環」と「からみ目」の関係に対応する 「トポロジー的に非等価な構造異性体」となり，一方，B 之 C は, 興味深いことに「単環」と「結び目」の関係に対応す る「トポロジー的に非等価なジアステレオマー」と分類さ れる。実際，両末端反応性 (2 官能性) 直鎖テレケリクスと 3 官能性カルボン酸対アニオン ${ }^{27) ， ま た は ~} 3$ 本鎖星形テレ ケリクスと 2 官能性カルボン酸対アニオンとの組み合わ せ汃 ${ }^{28)} ， \theta$ 型高分子 $\mathrm{A}$ ，手錠型高分子 $\mathrm{B}$ の混合物が得ら れ (図 4), 逆相クロマトグラフィーによって両者が分離で きることが確かめられた。A と B の生成比は高分子末端が ランダムに連結したときの予測值に比べやや B の割合が 大きかった。また， 3 本鎖星形テレケリクスと 3 官能性力 ルボキシレートとの反応では， $\theta$ 型高分子 $\mathrm{A}$ のみを選択的 に合成できる (図 4) ${ }^{29)}$ 。こうして得られた一連の多環状高 分子（たとえば $\theta$ 型高分子）は，特定の官能基を共通の高 分子フレームワーク中にさまざまに配置した酵素モデルと なることからあ興味深い。

\section{5. おわりに（お楽しみはこれから）}

本稿では，エレクトロニクスからバイオまで材料科学へ の幅広い応用に利用される,「役に立つ」高分子合成化学と は趣の異なる「高分子トポロジー化学」について紹介した。 この新しい高分子合成化学は，愉快なことに「超」基礎科 学である純粋数学の一分野 (トポロジー幾何学) に接点を あち, 今後この方面での学際的研究の進展にも期待した い。さらに Ring Family Tree（図 2) を眺めると，高分子 合成化学のフロンティアは大きく拡がっていることが実感 される。 $\alpha, \beta, \gamma$ ，および $\delta$ 型トポロジーをはじめとする多様 な「かたち」に魅惑されるのは筆者だけではないだろう。 筆者らの研究の「掞楽しみむこれから」に違いない。

謝 辞 本稿で紹介した研究は，多くの共同研究者（尾池秀章 助手・現 ERATO ナノ空間プロジェクトならびに学生諸君）のご
協力によって実施したあのです。また，ゼネラル石油研究奨励財 団, 岩谷直治記念財団, NEDO 材料ナノテクノロジープログラ ム・精密高分子技術プロジェクト，および文部科学省科学研究費 補助金による研究助成を頂戴しました。ここに記して謝意を表し ます。

\section{文献}

1) 手塚育志：未来材料， 4, $33(2004)$

2) 手塚育志：熱処理，44, 4 (2004)

3) 手塚育志：日本ゴム協会誌，75, 195 (2002)

4) Y. Tezuka: J. Polym. Sci., Part A: Polym. Chem., 41, 2905 (2003)

5) Y. Tezuka, H. Oike: Prog. Polym. Sci., 27, 1069 (2002)

6) Y. Tezuka, H. Oike: Macromol. Rapid Commun., 22, 1017 (2001)

7) Y. Tezuka, H. Oike: J. Am. Chem. Soc., 123, 11570 (2001)

8) E. Flapan: "When Topology Meets Chemistry: A Topological Look at Molecular Chirality," Cambridge University Press, Cambridge, UK, 2000

9) D. M. Walba: Tetrahedron, 41, 3161 (1985)

10) A. T. Balaban: Rev. Roum. Chim., 18, 635 (1973)

11) J. A. Semlyen, Ed.: "Cyclic Polymers," 2nd ed., Kluwer, Dordrecht, The Netherland, 2000

12) C. W. Bielawski, D. Benitez, R. H. Grubbs: Science, 297, 2041 (2002)

13) T. McLeish: Science, 297, 2005 (2002)

14) Y. Tezuka: Prog. Polym. Sci., 17, 471 (1992)

15) H. Oike, H. Imaizumi, T. Mouri, Y. Yoshioka, A. Uchibori, Y. Tezuka: J. Am. Chem. Soc., 122, 9592 (2000)

16) H. Oike, T. Mouri, Y. Tezuka: Macromolecules, 34, 6592 (2001)

17) H. Oike, M. Hamada, S. Eguchi, Y. Danda, Y. Tezuka: Macromolecules, 34, 2776 (2001)

18) Y. Tezuka, K. Mori, H. Oike: Macromolecules, 35, 5707 (2002)

19) H. Oike, M. Washizuka, Y. Tezuka: Macromol. Rapid Commun., 22, 1128 (2001)

20）塩澤 充，手塚育志：第 53 回高分子学会年次大会, IIF06 (2004)

21) H. Oike, S. Kobayashi, T. Mouri, Y. Tezuka: Macromolecules, 34, 2742 (2001)

22) H. Oike, T. Mouri, Y. Tezuka: Macromolecules, 34, 6229 (2001)

23) Y. Tezuka, R. Komiya, M. Washizuka: Macromolecules, 35, 12 (2003)

24) J. J. Berzelius: Prog. Ann., 19, 305 (1830)

25) F. A. Kekulé: Ann. Chem., 106, 129 (1858)

26) J.-P. Sauvage, C. Dietrich-Buchecker, Eds.: "Molecular Catenanes, Rotaxanes and Knots," Wiley-VCH, Weinheim, 1999

27) Y. Tezuka, A. Tsuchitani, H. Oike: Polym. Int., 52, 1579 (2003)

28) Y. Tezuka, A. Tsuchitani, H. Oike: Macromol. Rapid Commun., in press.

29) Y. Tezuka, A. Tsuchitani, Y. Yoshioka, H. Oike: Macromolecules, 36, 65 (2003) 